\title{
MISCELLANEA
}

\section{The Employment of Diabetics}

\section{JOHN F. COPPLESTONE}

\author{
From the Department of Health, Dunedin, New Zealand
}

(RECEIVED FOR PUBLICATION JULy 24, 1958)

Few studies have been made of the employability of diabetics, and recommendations concerning their employment are usually based on general principles. It is often considered that diabetics who are taking large doses of insulin should not be given work in which hypoglycaemic attacks might result in injury to themselves or others. However, the severity of an insulin reaction is now known not to be commensurate with the extent of hypoglycaemia; the dosage of insulin has no relationship to liability to reactions.

A survey has been undertaken of the employment experience during the preceding five years of 88 diabetics who attended the Dunedin Clinic during four months of 1957. There was some tendency for diabetics to take sedentary work. The occurrence of insulin reactions did not handicap these patients in varied types of occupations nor in driving vehicles, nor was there any evidence of an increased number of accidents in those who were liable to insulin reactions. Only about half the employed diabetics regularly carried an identification card; several, including two who were liable to severe reactions, had kept their condition secret from their employers and fellow employees.

It is concluded that the employment of diabetics needs to be limited only by their stamina, the presence of complications, and by their own good sense. Owing to the lack of objective information on the employment of diabetics it is urged that further surveys should be undertaken with the object of freeing diabetics from needless restrictions.

The prevalence of diabetes mellitus has been variously estimated at between 0.5 and $2 \%$ of the population in Great Britain and the United States. No figures of prevalence are available for New Zealand, but on this basis it might be expected that at least 3,000 diabetics are in gainful employment there. The problem of the hazards that diabetics may cause to themselves and their fellow workers is therefore important.

On diagnosis consideration must be given to the effect that the disease will have on the daily life of the patient, for the diabetic, more than most, must learn to live with his disease. The patient must necessarily rely on the advice of his doctor and this advice should not be lightly given where the occupation of the patient is concerned. Most published papers have been based on general principles, bearing in mind the possible complications of the disease and its treatment. In the United States, definite standards for employment were laid down by the American Diabetes Association in 1952. These state, inter alia, that the diabetic should be under regular medical care with an annual physical examination, that his condition should be known to his employer and key personnel, that he should always carry an identification card or tag, and that:

"Diabetics are capable of performing any type of work for which they are physically, mentally, and educationally equipped. Those diabetics who are taking large doses of insulin should not, however, be assigned work in which hypoglycaemic attacks may result in injury to themselves or others.'

The danger of the hypoglycaemic reaction has dominated the advice given in the literature. However, in relation to the amount of admonition, the amount of objective information on the employment of diabetics is small. Brandaleone and Friedman (1953) found that of 63 firms in the United States who replied to a questionnaire, 43 employed diabetics but 33 of these restricted diabetics to occupations without hazards. The same authors analysed the records of more than 3,000 employees in a transport system in which were included 40 diabetics. They found that the accident and sickness absence rates of diabetics did not differ from those of other employees. A survey by the United States Department of Labor quoted by McKendry (1955) gave a similar finding, except that the sickness absence rate for diabetics was slightly elevated due to the prolonged absence of a few individuals. Beardwood (1950) quotes the experience of 18 years of 110 diabetics in a public utility company employing 7,000 ; the absenteeism of the diabetics was $33 \%$ below the average. Elstad (1946) gives the results of a followup of 154 men who were treated for diabetes in Norway between 1930 and 1939. Eighty-seven per cent of these required more than 20 units of insulin daily and half were classed as heavy workers. Eighty-seven per cent considered themselves completely fit for work and were continuing in their previous occupations, while $7 \cdot 2 \%$ were partially fit, having been forced to change to a more suitable occupation.

The number of diabetics treated with insulin is probably higher among those of working age than among diabetics as a whole. Every diabetic on insulin is liable to have a hypoglycaemic reaction, irrespective of past experience, resulting from the introduction of new factors into his condition. The restrictions that should be placed upon a diabetic are of vital importance to the individual. Even as regards driving, there is no certainty of knowledge, for the Lancet (annotation, 1957) asks: "How dangerous is a diabetic in charge of a motor car?".

In this paper are reported the results of a survey designed to give an indication of the answers to these questions.

\section{The Survey}

During a period of four months, from August to November, 1957, patients attending the Diabetic Clinic 
of the Dunedin Hospital were interviewed, and a form was completed by the interviewer. Of the 89 patients seen, one middle-aged woman declined the recording of the information given and has therefore been omitted from the survey. The age and sex composition of the survey group is shown in Table 1.

There is a preponderance of the older age groups, 61 patients being aged 46 years or more.

\section{Results}

Table 2 embodies the results obtained in the enquiries regarding occupation over the preceding five years. Occupations have been classified under five headings
TABLE 1

AGE AND SEX OF SURVEY GROUP OF DIABETICS

\begin{tabular}{c|c|c|c}
\hline Age & Male & Female & Total \\
\hline Under 30 & 6 & 8 & 14 \\
31 to 45 & 7 & 6 & 13 \\
46 to 60 & 18 & 10 & 28 \\
Over 60 & 17 & 16 & 33 \\
\hline Total & 48 & 40 & 88 \\
\hline
\end{tabular}

according to energy expenditure. Sedentary work is self-explanatory and includes clerical work and work done seated at machines. Ambulatory work involves

TABLE 2

OCCUPATIONAL STATUS, EMPLOYMENT HISTORY, AND RELATIONSHIP TO TREATMENT, HAZARDS, AND DISABILITIES

\begin{tabular}{|c|c|c|c|c|c|c|c|c|c|c|}
\hline & \multicolumn{9}{|c|}{ Oscupation (Present or Last Job) } & \multirow[b]{2}{*}{ Total } \\
\hline & Sedentary & $\begin{array}{c}\text { Ambu- } \\
\text { latory }\end{array}$ & $\begin{array}{c}\text { Light } \\
\text { Manual }\end{array}$ & $\begin{array}{l}\text { Medium } \\
\text { Manual }\end{array}$ & $\begin{array}{l}\text { Heavy } \\
\text { Manual }\end{array}$ & \begin{tabular}{|c|} 
Total \\
Employed \\
Group
\end{tabular} & $\begin{array}{c}\text { House- } \\
\text { wives }\end{array}$ & Retired & $\begin{array}{c}\text { School } \\
\text { Children }\end{array}$ & \\
\hline Number of patients & 21 & 15 & 7 & 9 & 2 & 54 & 21 & 12 & 1 & 88 \\
\hline $\begin{array}{l}\text { Treatment } \\
\text { On insulin : } \\
\text { No reactions } \\
\text { Mild reactions } \\
\text { Severe reactions } \\
\text { No insulin }\end{array}$ & $\begin{array}{r}13 \\
4 \\
6 \\
3 \\
8\end{array}$ & $\begin{array}{r}12 \\
2 \\
9 \\
1 \\
3\end{array}$ & $\begin{array}{l}5 \\
1 \\
2 \\
2 \\
2\end{array}$ & $\begin{array}{l}\frac{4}{2} \\
2 \\
5\end{array}$ & $\begin{array}{l}2 \\
1 \\
- \\
-\end{array}$ & $\begin{array}{r}36 \\
8 \\
20 \\
8 \\
18\end{array}$ & $\begin{array}{r}11 \\
3 \\
5 \\
3 \\
10\end{array}$ & $\begin{array}{l}8 \\
2 \\
5 \\
1 \\
4\end{array}$ & $\begin{array}{l}1 \\
= \\
-\end{array}$ & $\begin{array}{l}56 \\
14 \\
30 \\
12 \\
32\end{array}$ \\
\hline $\begin{array}{l}\text { Employment History in Past Five Years } \\
\text { 1. No change: } \\
\text { Still in same job as before } \\
\text { diagnosis } \\
\text { Job begun since diagnosis }\end{array}$ & $\begin{array}{l}6 \\
3\end{array}$ & $\begin{array}{l}4 \\
4\end{array}$ & $\underline{2}$ & $\frac{7}{-}$ & $\underline{2}$ & 21 & & & & \\
\hline Total no change & 9 & 8 & 2 & 7 & 2 & 28 & & & & \\
\hline $\begin{array}{l}\text { 2. Permanently left Employment } \\
\text { Before diagnosis: Married } \\
\text { Retired } \\
\text { After diagnosis: } \begin{array}{l}\text { Married } \\
\text { Retired }\end{array}\end{array}$ & & & & & & $\begin{array}{l}-3 \\
\mathbf{3} \\
\mathbf{3}\end{array}$ & & & & \\
\hline $\begin{array}{l}\text { Total permanently left } \\
\text { employment }\end{array}$ & & & & & & 10 & & & & \\
\hline $\begin{array}{l}\text { 3. Changed Job } \ddagger \\
\text { Before diagnosis: Social reasons } \\
\text { Ill-health } \\
\text { "Too hard" } \\
\text { After diagnosis: Social reasons }\end{array}$ & $\overleftrightarrow{1}$ & -1 & $\rightarrow 1$ & $\overline{-1}^{1}{ }^{*}$ & & $\begin{array}{l}2 \\
2 \\
1 \\
5\end{array}$ & & & & \\
\hline III-health & 2 & $\stackrel{1 *}{\longleftarrow}$ & & & & 4 & & & & \\
\hline $\begin{array}{l}\text { "Too hard" } \\
\text { "Too dangerous" }\end{array}$ & & $\longleftarrow$ & -二 & -1 & & i & & & & \\
\hline Total changed job & 6 & 3 & 1 & 6 & - & 16 & & & & \\
\hline $\begin{array}{l}\text { Liability to Hazards } \\
\text { Machinery } \\
\text { Heights } \\
\text { Burns }\end{array}$ & $\frac{3}{-}$ & $\frac{1}{-}$ & $\begin{array}{l}3 \\
2 \\
1\end{array}$ & $\begin{array}{r}2 \\
2 \\
-\end{array}$ & $\begin{array}{l}1 \\
-\end{array}$ & $\begin{array}{r}10 \\
5 \\
1\end{array}$ & & & & \\
\hline Total liable & 3 & 1 & 6 & 4 & 2 & 16 & & & & \\
\hline Lost Time-Industrial Conditions & - & - & 1 & - & 1 & 2 & & & & \\
\hline $\begin{array}{l}\text { Other Illnesses and Disabilities } \\
\text { Complications of diabetes: } \\
\text { Disabling } \\
\text { Non-disabling } \\
\text { Complaints of tiredness } \\
\text { Unrelated conditions: } \\
\text { Disabling } \\
\text { Non-disabling }\end{array}$ & $\begin{array}{c}2 \\
2 \\
1 \\
-3\end{array}$ & $\begin{array}{c}3 \\
1 \\
1 \\
-1\end{array}$ & $\begin{array}{r}1 \\
-1 \\
-1\end{array}$ & $\begin{array}{r}3 \\
1 \\
- \\
-\end{array}$ & $\begin{array}{l}\overline{1} \\
\overline{1}\end{array}$ & $\begin{array}{l}9 \\
5 \\
4 \\
1 \\
5\end{array}$ & $\begin{array}{r}5 \\
2 \\
9 \\
-4\end{array}$ & $\frac{5}{-}$ & $\begin{array}{l}\bar{z} \\
\overline{-}\end{array}$ & $\begin{array}{r}19 \\
7 \\
13 \\
3 \\
12\end{array}$ \\
\hline
\end{tabular}

*Unemployed at present time. 
continuous walking and standing without other significant expenditure of physical effort. Such workers as shop assistants, a police constable, a wool-classer, a charge attendant in a mental hospital, and a welfare officer are among those included in this category. The light manual workers include printers, painters, and bookbinders: medium manual work denotes such jobs as motor mechanic, builder, joiner, and labourer. The two heavy manual workers were employed as boilermaker and fireman. In allotting occupations to these categories, careful note was made of the actual nature of the job and its demands on the patient. This seemed to be more realistic than an arbitrary allocation of a particular job to a single category. An elderly woman living alone was classed as a housewife, but if she lived with relatives or in a home has been placed in the retired category.

Patients who left employment permanently during the five-year survey period are classified under the last occupations held. At the beginning of the survey period 54 patients $(61.4 \%)$ were employed. In addition 21 $(23.8 \%)$ were housewives, $12(13.8 \%)$ had retired, and one was still at school. Ten of the employed group left their employment permanently during the survey period, four on marriage and six on retirement.

Thirty-six $(66.6 \%)$ of the employed group were treated with insulin and 28 of these experienced reactions outside hospital. In eight cases, the reactions were severe, involving unconsciousness. In those not employed, $20(60.0 \%)$ were on insulin and 14 of these had experienced reactions, four of them severely. Of those not on insulin, eight were under treatment by other medication at the time of interview, four of them in the employed group. These have not been considered separately from others not on insulin.

Over half the employed group were in the same occupation throughout the survey period, 21 in the same job that they had held before diagnosis and seven in jobs taken since diagnosis. Cases 1 and 2 are examples of those who remained in the same job.

Case 1.-J.A., a man, aged 47, a diabetic on insulin since the age of 32 , has been a boilermaker for 30 years and works an average of 12 hours a week overtime. He experiences occasional mild reactions in the form of dizziness lasting a few minutes, for which he takes glucose. His recent absences from work have been due to a fractured toe and an operation (left mastectomy). He rides a bicycle and has never had an accident on it.

Case 2.-A.S., a man, aged 47 , has taken insulin since the age of 33. For the last 11 years he has been a departmental manager in charge of 20 to 26 men. A sensation of tingling in the limbs presages occasional mild reactions. He drives a car at work and has had no accidents. He says that his only disadvantage is irregularity of meals while travelling. An early right cataract has been diagnosed this year.

Of the 16 who changed their jobs during the survey period, five did so before diagnosis, and 11 after the diagnosis of diabetes had been made. Social reasons accounted for two of the former and five of the latter changes.

At the time of interview, the following two patients were unemployed:
Case 3.-E.T., a man, aged 50, developed ulcers of the feet 16 months ago. Investigation revealed diabetes and he was treated with insulin. Before diagnosis he had been employed in the Public Service as a labourer for four years but has not worked since the ulcers developed. (Since these figures were abstracted, this man has returned to work.)

Case 4.-G.S., a man, aged 57, a diabetic on insulin since the age of 41 , is subject to occasional mild reactions. He has been in receipt of social security benefit for two years on account of labyrinthine disturbances which caused him to leave his last occupation as shop assistant after one year. Before that he had been a driver but had to leave this work on account of angina following a coronary thrombosis in 1949 . He was unemployed for a few months between these two jobs.

Of the remaining two changes made before diabetes was diagnosed, one was due to ill-health; the patient took a lighter job on the railway after a coronary thrombosis. In the second a policeman found a country job in sole charge too hard in view of the large garden for which he was responsible, and transferred to a sedentary job in the police force.

Apart from the patient still unemployed (Case 4), three others changed their occupation due to ill-health, after the diagnosis of diabetes was made, one on account of the onset of blindness which ended his clerical life: he is now employed on making cardboard boxes. Another changed to lighter work as a stores clerk after amputation of the right leg for gangrene. The third case is instructive:

Case 5.-S.M., a man, aged 46, was diagnosed and treated with insulin at the age of 40 . At that time he was a building foreman but his employment on a variety of different tasks made him difficult to stabilize. Four years ago he became a building teacher and has had no reactions recently. He is still exposed to the hazards of machines and saws and drives a car without difficulty or accidents.

One man left his work because he considered it too hard:

Case 6.-J.C., a man, aged 48, a diabetic on insulin since the age of 29 , was subject to occasional mild reactions in the early morning. Until 12 years ago he was a labourer in a butter factory. He found this too hard and spent the next 10 years on social security benefit. He was advised by his doctor to give this up and two years ago became a mess steward at which he has since been happily employed.

Another left his work because he considered it too dangerous:

Case 7.-R.B., a man, aged 23, on insulin since the age of 11 , was subject to severe reactions, during which he is unconscious for a short time. These are preceded by a brief aura and have occurred four times in the last nine months. He was employed as a sedentary machinist but left nine months ago as he considered this work to be too dangerous although he had not had any accidents. $\mathrm{He}$ is now employed as a labourer. He rides a bicycle and has had no road accidents.

In the employed group of 54 patients, 10 are subject to hazards from machinery, five work at heights, and one is exposed to danger from burns. Two patients had lost 
time in the last five years on account of industrial accidents: one was the boilermaker with a fractured toe (Case 1), a common accident in his trade, and the other was a painter who was blown off his ladder by the wind. There is therefore no evidence of an excess of industrial accidents among the diabetics included in this survey.

The final section of Table 2 shows the incidence of complications of diabetes and of unrelated conditions in the whole survey group. The complications of diabetes have been given a wide definition and the 19 disabling cases include five patients who share a common fundamental pathology of atheroma. Five cases have complications affecting the circulation in the legs and feet and three others have had insulin reactions of such severity as to require admission to hospital. Six patients have defects of vision, of whom three are blind. One of these has already been mentioned, and one is retired. The third case is described below:

Case 8.-D.B., a man, aged 30 , on insulin since the age of 8 , occasionally has mild reactions. He became blind (6/60 in both eyes) in 1950, before which he was employed as an accountant. This was followed by a period of unemployment and training at the Blind Institute. He has been usefully employed as a welfare officer for the blind for over five years.

A special note was made of complaints of tiredness where no other complication was found. No interrogation was made on this point and the complaints were all spontaneous. Four $(7 \cdot 4 \%)$ of the employed group and nine $(36 \%)$ of the housewives volunteered this information.

Of the 25 housewives interviewed, four had married within the last five years. Among them they cared for 43 dependants (average 1.7 each) including five preschool children. Three of the housewives were pregnant. The nine who complained of excessive tiredness cared for 22 dependants including four of the pre-school children, an average of 2.4 dependants each. None of the housewives employed help in the house, and tiredness may have been a complication of being a housewife with a family rather than a complication of diabetes.

In the retired group, which numbered 18 at the end of the enquiry, eight had retired before the diagnosis of diabetes was made, six on age, and two on account of ill-health. One patient retired on grounds of ill-health at the age of 69 after a series of operations including cholecystectomy and herniorrhaphy and the other at the age of 60 (four years before diagnosis) on account of unspecified ill-health after working long hours during the second war. One patient retired on age grounds in the year of diagnosis and nine have retired since the diagnosis of diabetes, four of them on grounds of age. Five retired on account of ill-health and in four of these diabetes or its complications was responsible. Details of these five cases are shown in Table 3.

Three of the eight patients who retired before the diagnosis of diabetes had been made were women; the five men in this group retired at an average age of 66 years. Of the nine patients who retired after diagnosis, two were women; the average age of the seven men on retirement was 65 years.
TABLE 3

RETIREMENT ON ACCOUNT OF ILL-HEALTH AFTER DIAGNOSIS OF DIABETES

\begin{tabular}{|c|c|c|c|c|}
\hline $\begin{array}{l}\text { Case } \\
\text { No. }\end{array}$ & $\begin{array}{l}\text { Age at } \\
\text { Time of } \\
\text { Enquiry } \\
\text { (years) }\end{array}$ & $\begin{array}{c}\text { Age at } \\
\text { Diagnosis } \\
\text { (years) }\end{array}$ & $\begin{array}{c}\text { Age of } \\
\text { Retirement } \\
\text { (years) }\end{array}$ & Reason \\
\hline $\begin{array}{r}9 \\
10 \\
11 \\
12\end{array}$ & $\begin{array}{l}72 \\
78 \\
70 \\
75\end{array}$ & $\begin{array}{l}60 \\
55 \\
58 \\
43\end{array}$ & $\begin{array}{l}63 \\
73 \\
59 \\
71\end{array}$ & $\begin{array}{l}\text { Diabetes unspecified } \\
\text { Tuberculosis } \\
\text { Blindness } \\
\text { Age grounds but occa- } \\
\text { sional severe reactions }\end{array}$ \\
\hline 13 & 60 & 55 & 57 & $\begin{array}{l}\text { Unspecified ill-health } \\
\text { due to first war in- } \\
\text { juries }\end{array}$ \\
\hline
\end{tabular}

Apart from occupational details, questions were asked on three other points. The first two of these were suggested by the standards of employment of the American Diabetic Association and concerned the carriage of diabetic cards and the information given by the diabetic to his employer. At the Dunedin Clinic every patient on insulin is issued with a diabetic card. The answers given by patients on insulin to the question, "Do you carry your card?" are analysed in Table 4.

TABLE 4

CARRIAGE OF DIABETIC CARDS BY PATIENTS ON INSULIN

\begin{tabular}{c|c|c|c}
\hline Card Carried & Always & Sometimes & Never \\
\hline Total & 24 & 8 & 24 \\
\hline Sex: Males & 12 & 5 & 11 \\
Fge: Under 30 & 12 & 3 & 13 \\
31 to 45 & 7 & 1 & 6 \\
46 to 60 & 3 & 3 & 4 \\
Over 60 & 6 & 2 & 7 \\
Reactions: None & 8 & 2 & 7 \\
Mild & 6 & 1 & 13 \\
Severe & 12 & 5 & 4 \\
\hline
\end{tabular}

Age, sex, and, surprisingly, liability to reactions appeared to have no relation to the carriage of a diabetic card by patients on insulin.

TABLE 5

KNOWLEDGE OF CONDITION BY EMPLOYER AND OTHER EMPLOYEES

\begin{tabular}{|c|c|c|c|c|c|c|}
\hline \multirow{3}{*}{$\begin{array}{c}\text { Treatment } \\
\text { Status }\end{array}$} & \multicolumn{5}{|c|}{ Condition } & \multirow{3}{*}{$\begin{array}{c}\text { Not } \\
\text { Applicable }\end{array}$} \\
\hline & \multicolumn{2}{|c|}{$\begin{array}{l}\text { Known to } \\
\text { Employer }\end{array}$} & \multicolumn{3}{|c|}{$\begin{array}{l}\text { Known to } \\
\text { Employees }\end{array}$} & \\
\hline & Yes & No & Yes & No & $\begin{array}{c}\text { Not* } \\
\text { Applicable }\end{array}$ & \\
\hline $\begin{array}{l}\text { On insulin } \\
\text { No insulin }\end{array}$ & $\begin{array}{l}32 \\
11\end{array}$ & $\begin{array}{l}4 \\
2\end{array}$ & $\begin{array}{l}29 \\
13\end{array}$ & $\begin{array}{l}4 \\
4\end{array}$ & $\begin{array}{l}3 \\
1\end{array}$ & $\begin{array}{l}20 \\
14\end{array}$ \\
\hline Totals & 43 & 6 & 42 & 8 & 4 & 34 \\
\hline
\end{tabular}

Table 5 shows the answers obtained to questions on whether the diabetic state was known to the employer or fellow employees. Of the diabetics on insulin, four have kept their condition secret from both employer and fellow workers. All of these were subject to reactions, with a liability to unconsciousness in two cases. 
Finally, the patients were asked whether or not they drove a motor vehicle or rode a bicycle and whether they had had any road accidents in the last five years. The answers are summarized in Table 6.

TABLE 6

DRIVING HABITS, INSULIN REACTIONS, AND ACCIDENTS IN LAST FIVE YEARS

\begin{tabular}{|c|c|c|c|c|c|}
\hline & \multirow{2}{*}{ Insulin } & \multirow{2}{*}{$\begin{array}{c}\text { No } \\
\text { Insulin }\end{array}$} & \multicolumn{3}{|c|}{$\begin{array}{l}\text { Liability to Reactions of } \\
\text { Patients on Insulin }\end{array}$} \\
\hline & & & Nil & Mild & Severe \\
\hline $\begin{array}{l}\text { Motor vehicles } \\
\text { Bicycles } \\
\text { Pedestrians }\end{array}$ & $\begin{array}{l}18 * * \\
9 \\
29 *\end{array}$ & $\begin{array}{c}10^{* *} \\
3 \\
19\end{array}$ & $\begin{array}{l}4^{* *} \\
8^{*}\end{array}$ & $\begin{array}{r}11 \\
3 \\
16\end{array}$ & $\begin{array}{l}3 \\
4 \\
5\end{array}$ \\
\hline Totals & $56^{* * *}$ & $32 * *$ & $14^{* * *}$ & 30 & 12 \\
\hline \multicolumn{6}{|c|}{ 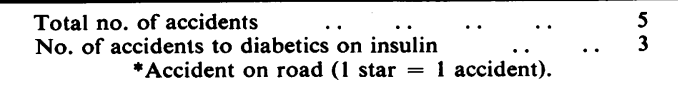 } \\
\hline
\end{tabular}

Twenty-eight patients drove motor vehicles, two drove lorries, seven business cars, and the remainder private cars. Eighteen of the drivers took insulin and 14 of these were subject to reactions. Twelve, nine of them on insulin, rode bicycles. There were five accidents in the five-year survey period, three of them affecting insulintreated diabetics. Two of these were drivers of business cars who drove a considerable mileage every year and one was a pedestrian who fell from a bus. The interesting point is that none of the patients involved in an accident was subject to insulin reactions.

\section{Discussion}

The main disadvantage of a survey of this type is the difficulty of assessing the reliability of the information provided. In each case the purpose of the survey was explained and it was emphasized that the name or address of the employer was not required. The attitude of the patients was such as to lead to no doubts of their veracity. Although the number of patients included is not large the age and sex representation is characteristic of diabetics as a whole.

No attempt has been made to estimate the insulin dosage of those so treated. Joslin, Root, White, and Marble (1952) have pointed out that the severity of an insulin reaction is by no means definitely commensurate with the extent of hypoglycaemia and it appears to be generally accepted that the dosage of insulin has no relationship to liability to reactions. Every diabetic on insulin may be considered to be liable to experience reactions. The facts elicited in this survey indicate that in nearly all cases occupation had not been materially affected even when insulin reactions occur. It is chiefly the complications of diabetes that have caused a change of occupation on medical grounds and generally this has been to lighter work, although not necessarily to work devoid of hazards, as indicated by Case 5. Case 6 shows that even cases which have been on social security benefit for several years can be satisfactorily settled in employment. There appears to be a tendency for diabetics to take sedentary work. Twenty-one of the 54 in the employed group were so employed, including six of the
21 who were still in the same job as before diagnosis. The national proportion employed in sedentary posts is unknown but the observation is interesting in view of the suggestion of Barach (1949) that " if a pair of identical twins, equally susceptible to diabetes, were so placed that one was to become a coal-miner and the other a clerk ...., the one who earned his bread by the sweat of his brow would certainly not be the first to develop diabetes: better still he might not develop it at all ".

Although a number of the diabetics on insulin included in this survey were exposed to real hazards, the liability to insulin reactions did not appear to have affected the accident rate. None of the accidents reported appears to have had any relationship to an insulin reaction and it does not seem likely that this information was concealed when road accidents were readily reported. On the other hand the failure of four cases to reveal their condition to their employers may indicate a belief on their part that there is a prejudice against diabetics in industry.

Complaints of excessive tiredness were most evident among housewives. This might reflect the inability of the housewife to change her occupation if she feels her job is becoming too hard. No relationship was found between occupation as a causative factor and the incidence of other complications of diabetes. However, complications sometimes forced a change of employment, or incapacitated the patient in severe cases. This was especially true of eye and foot complications.

Many patients failed to carry diabetic cards, although this is a commonsense precaution. In the United States it has been recommended that the carriage of such cards by diabetics should be a prerequisite for employment. It would seem at least that more effort might be made by the medical profession to ensure that these cards are carried. An occasional re-issue of cards to all patients by the diabetic clinic would be one approach to this problem.

As far as the law is concerned, the diabetic driver has long been in a difficult position, and this has recently been made worse in the United Kingdom by a decision on appeal by the Divisional Court of the Queen's Bench Division (Armstrong v. Clark, 1957). The Lord Chief Justice stated that insulin was clearly a drug under the Road Traffic Act (1930), and continued by saying that if people were in a condition of health which either of itself rendered them liable to go into a coma or the remedies for which might send them into a coma, they must not drive because of the danger that would result to the rest of Her Majesty's subjects. No evidence of such danger was found in the present survey, which underlines the need for more objective data if diabetics are not to be unfairly penalized.

The public attitude to diabetics has been moulded by the medical profession, whose advice has been based on the assumption that patients should not be placed in a position in which they might injure themselves or others should an insulin reaction occur. While the evidence gathered in this survey is not conclusive because of the small number of cases involved, it suggests that many diabetics do place themselves in potentially dangerous positions; even if they had reactions, no harm appears to have ensued to the patients surveyed. The assumption 
made by the Lord Chief Justice and by many doctors that, where a person is liable to become unconscious, danger exists, is correct on strictly logical grounds. However, when all the characteristics of diabetes mellitus are considered, the position in respect of this disease is seen to be somewhat different.

The diabetic is not in the same category as many epileptics on whom complete unconsciousness is liable to descend with great suddenness. Most diabetics understand the mechanics of their condition fairly well: they know the time of day in which insulin reactions are liable to occur: they know how to treat reactions and usually carry sugar with them: and, most important of all, they usually have sufficient warning to take remedial measures before their consciousness becomes clouded. This applies even to many patients who have severe reactions. The patients who fail to wake in the morning are those in whom normal sleep has masked the premonitory signs and this has no influence on their employability, even if it may occasionally affect their punctuality.

\section{Conclusion}

It would appear, therefore, from this survey that many of the restrictions placed on diabetics are unnecessary: their potentiality for employment is limited solely by their stamina, by the presence of any organic complications of their disease, and by their own good sense. If these results are confirmed by other surveys, and the need for these is great, most diabetics should be freed from needless restrictions in the choice of their occupation.

I am indebted to Dr. J. A. Kilpatrick, physician of the Dunedin Hospital, for access to his patients and for his helpful advice and criticism in preparing this paper, and to Miss A. J. Smellie, public health nurse, for assistance in the collection of data, and to the Director-General of Health, New Zealand, for permission to publish.

\section{REFERENCES}

American Diabetes Association (1952). Statement of the Committee on Employment. Diabetes, 1, 336.

Annotation (1957). Lancet, 1, 310.

Armstrong v. Clark (1957). “" Medicine and the Law." Ibid., 1, 319. Barach, J. H. (1949). Diabetes and Its Treatment, 1st. ed., p. 27. Oxford University Press, New York.

Beardwood, J. T. (1950). Industr. Med. Surg., 19, 271.

Brandaleone, H., and Friedman, G. J. (1953). Diabetes, 2, 448.

Elstad, D. (1946). Nord. Med., 31, 1807.

Joslin, E. P., Root, H. F., White, P., and Marble A. (1952). The Treatment of Diabetes Mellitus, 9th ed., p. 309. Lea and Febiger, Philadelphia.

McKendry, J. B. R. (1955). Occup. Hlth Rev., 6, No. 2, p. 18.

\section{Correction}

In the article " Respiratory Function of Witwatersrand Goldminers: A Comparison between Radiologically Normal Miners and Control Non-mining Subjects"' (Brit. J. industr. Med., 15, 258) there is an error in Table 3 (p. 26), in the column "Fall in Compliance on Hyperventilation at $f \pm 50 / \mathrm{min}$.":-

51-60 years railway workers should be -0.019 not -0.083

S. D. should be $\mathbf{0 . 0 3 6}$ not 0.094

\section{BOOK REVIEWS}

A Short History of Public Health. By C. Fraser Brockington. (Pp. vii +235 . 15s.) London: J. \& A. Churchill. 1956.

A reviewer is sometimes tempted to ask, Is this book really necessary? The question is especially pertinent in this instance since, from Simon to Frazer, public health has been well served by its historians. A new version is, therefore, justified only if it offers a different approach or provides some new insights into the wellknown narrative. Professor Fraser Brockington's latest book sets out to do this.

The book is divided into two parts; the first, which consists of a concise account of the history of public health in this country, provides the background for the second part, in which some of the major topics in this field are selected for fuller historical treatment and discussion.

On the whole the result is very satisfactory, although the book is not without its faults. The "short" history contained in Part I does not belie the title. The growth of public health during the past two centuries is covered in about 60 pages. This has involved a considerable degree of compression. In fact, compression has, at times, been carried too far and so given rise to such statements as that William Farr " observed the correlation between cholera and water supplies" (p. 25). A naive student or a sophisticated statistician might gather from this that the incidence of cholera in an area is a function of the volume of water consumed or available. There are inaccuracies, too: the first medical officers of health in the Metropolitan districts were not "appointed on the instruction of the General Board of Health" (p. 24) but through the Metropolis Management Act of 1855; John Snow did not confront "the parish council" about the Broad Street pump (p. 25), it was the Board of Guardians. And, unfortunately, the hospital services today do not cost $£ 300,000$ (p. 60), but this may be a typographical error of which there are a number, especially in the index.

The second part, which occupies two-thirds of the book, is much better done, These eight chapters are devoted to the following subjects: the effects of economic and social changes on population, and the growth of community services for housing, maternal, and child health, neglected children, mental illness, tuberculosis, venereal disease, and the aged. In each case the historical account leads on to a discussion of current issues, which is both informative and thought-provoking.

Inevitably there are gaps. There is no mention of the school meals service and the free milk scheme in the chapter on the services for the child. This is perhaps to avoid duplicating the brief mention of these in Part $I$. Industrial health is not dealt with here, although the thread is woven into the general pattern of public health history in the first part. 